\title{
Investigation and Analysis of Sexual Harassment in Corporate Workplace of China
}

\author{
Xiaobing Zhang ${ }^{1}$, Zewei Zhang ${ }^{2}$ \\ ${ }^{1}$ Economics and Management School, Huaiyin Institute of Technology, Huai'an, China \\ ${ }^{2}$ Business Administration School, Guizhou Institute of Finance and Economics, Guiyang, China \\ Email: zhangxb3758@sina.com, 84975463@qq.com
}

Received March $4^{\text {th }}$, 2012; revised April 5 ${ }^{\text {th }}$, 2012; accepted May $12^{\text {th }}, 2012$

\begin{abstract}
At present, sexual harassment in domestic workplace has a high probability of occurrence, which causes more and more attention. In this paper, the form of sexual harassment in workplace, and how to solve the sexual harassment were investigated and analyzed through questionnaires; and countermeasures and management suggestions were put forward from three aspects of corporate, employees and family.
\end{abstract}

Keywords: Sexual Harassment; Workplace; Investigation; Suggestions; Countermeasures

\section{Introduction}

With the development of economy, gradually diversification and complication of social life, sexual harassment issues come into play. Sexual harassment has caused more and more attention and reflection. For a long time, people's understanding of sexual harassment is still quite vague. From a global perspective, many countries have legislation to make clear that sexual harassment is a crime, and various forms of severe punishment will be used to punish people for his harassment. In our country, so far, widespread sexual harassment in the workplace has become a social problem of affecting the lives, work and health of women, family stability, and social stability. Its high probability of occurrence and the severity of harm are far more than the imagination of people, so it is necessary to solve this problem as soon as possible. According to a questionnaire survey of 600 people in Shenzhen in 2009, 32 percent of respondents said they had been subjected to various forms of sexual harassment, in which female victims accounted for $43 \%$ of the total number of visits, male victims accounted for $19 \%$ of the total number of visits. Sexual harassment in work environment in China is becoming a social problem, and in some corporate, this problem has even reached a more serious level.

\section{Literature Review}

Sexual harassment is an exotic phrase, and known as sexual harassment in western countries. Sexual harassment is first put forward by American Women Jurists Catherine. She pointed out that sexual harassment is the behavior doing unwelcome, sex-related words, demands or actions to the woman, through the abuse of power in the workplace, schools, hospitals or other public areas, by bullying, intimidation, control means .

American College and University Personnel Association divides sexual harassment in the workplace into four cases: sexual harassment of the exchange of threatening, sexual harassment of making the work that people feel threatened, hostile, infringed, indirect sexual harassment and outsiders sexual harassment of providing special treatment to specific employees providing sexual services.

In China, people have paid attention to and studied the prob- lem of sexual harassment only in recent years. Sexual harassment is a hidden phenomenon. For a long time, very little attention was paid to some problems of subjecting to sexual abuse in different degrees in public place or work place. In comparison with international, there is lack of scale survey of the status of sexual harassment in China, but according to some local or small-scale survey, phenomenon of sexual harassment in China is increasingly common and growingly serious.

According to China's recently published several research shows that the serious state of such a problem in our country has been catching up with trends overseas. In recent years, many media have exposed a number of cases of sexual harassment cases, for example, a female teacher is sexually harassed by her boss, and the first case of sexual harassment in Xi'an went against because of insufficient evidence! These events caused much attention to sexual harassment issues (Shen, 2004).

Most of the current sexual harassment is sexual harassment in the workplace, and the type of sexual harassment produced much more serious consequences than sexual harassment in the public place. The consequences caused to the victims is not only sustained mental anguish, but also a direct result of the deterioration of working conditions, some of the victims are forced to resign in order to avoid sexual harassment, resulting in some economic loss (Wang, 1998). It can also lead to companies reduce productivity, pay compensation or fines. It will hinder the process of social equality, hinder productivity and social development.

In the European Community, sexual harassment of working women has been a serious problem. The survey of its members, such as Germany, France, the Netherlands and Denmark shows that sexual harassment at work is not an isolated phenomenon of single woman, but to the millions of women throughout the EC, sexual harassment has become an unpleasant unwanted part in their career (Wang, 1998).

\section{Investigation and Analysis of Sexual Harassment in Corporate Workplace}

\section{Research Objects}

The female employees of Nanjing Huahao Investment Co., 
Ltd. and Fidelity Life Insurance Co., Ltd. are chosen as research objects, because Nanjing gathering companies is the "high stress zone", the powerful economic strength, a wealth of information resources and the international status make people can not help feeling the pressure. Many women drowned in the environment, in order to live or achieve their ideal, often pay more effort than men. However, women are low capacity, strong hesitant, and more prone to psychological problems. Many enterprises in Nanjing, many different people come here to develop; each has different character and means of doing things, so the findings would be more diverse.

The standard sample was selected as the research objects with the method of random sampling, in order to narrow the scope of the study, to reduce the difficulty of the work, I mainly selected female employees of certain enterprises in Nanjing as samples, the survey conditions are: 1) the ages from 21 to 50 years old, that is sexual harassment-prone age; 2) have work experience of more than one year.

\section{Research Methods}

This study combined literature review, surveys. 123 questionnaires were sent out from March 28, 2011 to April 15, 2011, 100 available questionnaires were retrieved, of which 42 were sent out in writing by the author, the other 81 were sent out by e-mail.

\section{Research Process}

In this study the questionnaire of previous international research literature was used, and modified the initial scale by interview, and then the modified scale was used to test the respondents and reliability and validity of the test questionnaire was analyzed, finally compiled into a formal questionnaire. The questionnaire consists of two parts: background measurement and measurement of corporate sexual harassment. Background measurement part consists of gender, age, education, marital status, the nature of the enterprises, monthly income, and the nature of work and positions the eight items. The measurement part of corporate sexual harassment consists of seven questions, respectively put a question to the object of sexual harassment, the subject of sexual harassment, measures the object of sexual harassment may take to, the impact of sexual harassment on the psychology of the object, methods should be given when somebody suffered sexual harassment in the enterprise and how to better promote prevention of sexual harassment and other aspects of the question.

\section{Research Results}

The specific circumstance of the sample is shown in Table $\mathbf{1}$. The results are that sexual harassment more prone to occur in the place lack of system tradition and system protection.

Survey showed that verbal sexual harassment in the work environment is the principal form of sexual harassment. According to Table 2 shows, women having experienced verbal or attitude harassment in the corporate workplace accounted for $54 \%$ in this survey, the proportion is far higher than investigators initially expected.

According to Table $\mathbf{3}$ shows, survey also showed that require the competent unit process and report to the police are the main methods to deal with sexual harassment.
Table 1.

The situation of the formal investigation sample (100).

\begin{tabular}{|c|c|c|c|}
\hline Variable & Option & No. of person & Percentage \\
\hline \multirow{2}{*}{ Gender } & Male & 0 & $0 \%$ \\
\hline & Female & 100 & $100 \%$ \\
\hline \multirow{4}{*}{ Age } & $21-30$ & 40 & $40 \%$ \\
\hline & $31-41$ & 28 & $28 \%$ \\
\hline & $41-50$ & 27 & $27 \%$ \\
\hline & Above 50 & 5 & $5 \%$ \\
\hline \multirow{4}{*}{$\begin{array}{l}\text { Educational } \\
\text { level }\end{array}$} & $\begin{array}{l}\text { Under or equal to } \\
\text { secondary school }\end{array}$ & 2 & $2 \%$ \\
\hline & Senior high school & 12 & $12 \%$ \\
\hline & Junior college & 36 & $36 \%$ \\
\hline & Regular college & 50 & $50 \%$ \\
\hline \multirow{2}{*}{$\begin{array}{l}\text { Marital } \\
\text { status }\end{array}$} & Single & 72 & $72 \%$ \\
\hline & Married & 28 & $28 \%$ \\
\hline \multirow{4}{*}{$\begin{array}{l}\text { Monthly } \\
\text { income }\end{array}$} & Below 1000 yuan & 9 & $9 \%$ \\
\hline & 1000 - 3000 yuan & 54 & $54 \%$ \\
\hline & 3000 - 5000 yuan & 25 & $25 \%$ \\
\hline & Above 5000 yuan & 12 & $12 \%$ \\
\hline \multirow{5}{*}{ Work unit } & State-owned company & 11 & $11 \%$ \\
\hline & Private enterprise & 52 & $52 \%$ \\
\hline & Foreign-capital enterprise & 18 & $18 \%$ \\
\hline & Sino-foreign joint ventures & 7 & $7 \%$ \\
\hline & Institutions & 12 & $12 \%$ \\
\hline \multirow{5}{*}{$\begin{array}{l}\text { The nature } \\
\text { of the work }\end{array}$} & Production & 4 & $4 \%$ \\
\hline & Sales & 54 & $54 \%$ \\
\hline & Executive & 23 & $23 \%$ \\
\hline & Management & 19 & $19 \%$ \\
\hline & $\begin{array}{l}\text { Project (including research } \\
\text { and exploitation) }\end{array}$ & 0 & $0 \%$ \\
\hline \multirow{5}{*}{ Position } & General manager & 21 & $21 \%$ \\
\hline & Line manager & 46 & $46 \%$ \\
\hline & Middle manager & 16 & $16 \%$ \\
\hline & Senior manager & 0 & $0 \%$ \\
\hline & Other & 17 & $17 \%$ \\
\hline
\end{tabular}

\section{Countermeasures and Management Suggestions on Preventing and Solving Sexual Harassment in the Workplace}

\section{Countermeasures and Management Suggestions on Enterprise Preventing and Solving Sexual Harassment in the Workplace}

The Enterprise Should List the Related Content on Prevention of Sexual Harassment in the Internal Rules and Regulations

Enterprise, moreover, is the protector of workers' legitimate rights and interests. Business protecting the legal rights of workers, the first performance is to respect and understanding 
Table 2.

Encountered which form of sexual harassment.

\begin{tabular}{ccc}
\hline Option & No. of person & percentage \\
\hline Verbal or attitude & 54 & $54 \%$ \\
Physical behavior & 20 & $20 \%$ \\
Exchange condition & 8 & $8 \%$ \\
None & 18 & $18 \%$ \\
\hline
\end{tabular}

Table 3.

How to deal with sexual harassment.

\begin{tabular}{ccc}
\hline Countermeasures & No. of person & Percentage \\
\hline Hit back harasser on the spot & 4 & $4 \%$ \\
Curse harasser on the spot & 2 & $2 \%$ \\
Complain to family members or friends & 18 & $18 \%$ \\
Require the competent unit process & 27 & $27 \%$ \\
Report to the police & 25 & $25 \%$ \\
Turn to private organization for help & 13 & $13 \%$ \\
Tolerance & 1 & $1 \%$ \\
Regard as noting & 2 & $2 \%$ \\
Other & 8 & $8 \%$ \\
\hline
\end{tabular}

the workers, followed is to achieve the specific labor rights of workers. So companies in labor relations, bear an important responsibility to protect basic human rights of workers. Sexual harassment in enterprise workplace is against the sex right of the workers, will cause the victims' inner resentment and fear, resulting in the exclusion of sexual object, the rights of victims have been infringed seriously. Therefore, enterprises should establish appropriate rules and regulations to protect workers' basic rights, and create a harmonious, good working environment.

First, establish the related content of prevention sexual harassment in labor contracts. Employers are obligated to provide a fair, safe, no harm good working environment and working condition for workers. Second, establish disciplinary rules prohibiting sexual harassment, make clear the appropriate penalties of sexual harassment, and increase the punishment for sexual harassment. Third, determine there are employees to investigate and solve sexual harassment complaints in the specialized agencies. Workers suffering sexual harassment, can complain to the special department, and can require the perpetrator to apologize, in serious cases may require compensation. Disciplined services departments should identify the truth of the matter, and properly solve disputes between employees. On sexual harassment disputes between employees can not be solved on internal, victims should be informed to apply to departments concerned, and should support the victims to protect their legitimate rights and interests.

\section{Enterprises Should Strengthen the Transparency of the Workplace}

Whether sexual harassment in the workplace, or sexual harassment in public places, the perpetrator generally does not want people to know, such behavior has a certain degree of secrecy. Therefore, to reduce sexual harassment in the work- place, the transparency of the work environment should be strengthened. Business do not set too privacy space in the office environment, try to take collective office or cubicle-like office design, if they really need a separate office environment, can take a transparent glass design, not to create the objective conditions for sexual harassment. Try to avoid scheduling a man and a woman in a separate office. When employees who have been harassed required to exchange office or required additional staff in a separate place, the enterprise should give considerable attention, do not say "no evidence" or "later" to dodge. Qualified enterprises, under the premise of non-infringement the privacy of workers, can also install monitoring equipment in the workplace, which will play a role to avoid sexual harassment.

Sexual harassment prevention education should be carried out to staff. Companies should regularly or irregularly educate and train staff by a variety of ways to prevent sexual harassment, such as issuing manuals or posters, holding seminars, and incorporating film, video and other information.

Establish the sexual harassment prevention agencies. The agency's duties include deal with staff grievances responsibility and fairly; assess the effectiveness of sexual harassment policy and implementation process; supervise employees behavior in the workplace; pay close attention to the country legislation on sexual harassment, adore new measures or recommendations other organizations used in the prevention and treatment of sexual harassment and collect sexual harassment cases within and outside of organizations; improve continuously the prevention mechanism of sexual harassment within the organization.

\section{The Enterprise Should Establish the Equal Organizational Culture}

As long as there is inequality in society, anyone can become the object of sexual harassment from the subject of sexual harassment, or vice versa. Therefore, to eradicate sexual harassment, the key lies in creating an organizational culture with peace and equality, to promote respect and the values of equality in the organization, in order to create a gender equality and mutual respect working environment.

\section{Countermeasures and Management Suggestions on Employees Preventing and Solving Sexual Harassment in the Workplace}

For the workplace sexual harassment frequently occurs, enterprise employees should enhance self-protection, avoid becoming victims of sexual harassment. Firstly, we should pay attention to our dress and behavior in the workplace. Dress in the workplace should meet the needs of work and avoid wearing too revealing clothes. Behavior in the workplace should be generous, gestures should be consistent with our status, do not play some excessive jokes with others, to avoid too frivolous and impulsive behavior. Secondly, avoid to work overtime alone with the opposite sex boss or people with sexual harassment tendencies. Thirdly, sexual harassment occurring in his body should be severely prevented. The harassment of people is generally tentative for the first time, if the victims fear or compromise sexual harassment based on come consideration, it would encourage the arrogance of the perpetrators of sexual harassment, make themselves more and more disadvantageous position, the result will be gradually increased harassment, is 
illegal connivance, is not conducive to the prevention of sexual harassment and attack. The victims should defend their legitimate rights and interests consciously and courageously.

Major sexual harassment in the workplace is superiors sexually harass subordinates. Within the enterprise, the work and quality of staff is mainly based on the evaluation of the boss, so boss often sexually harass subordinates by it, and subordinates often keep tolerant for such acts based on promotion or keeping their jobs, but this will make perpetrator more reckless violations. To prevent sexual harassment fundamentally, the victims must have the courage to fight against sexual harassment, to protect their legitimate rights and interests. On the other hand, compared with the harasser, the victims of sexual harassment are often in a weak position, part of the victims will only yield and obey in order to prevent future retaliation from harasser in the sexual harassment. This is connivance and accommodation to illegal behavior, which will make the perpetrator of sexual harassment more furious, so when facing the sexual harassment, the victims should eliminate the concerns, have the courage to fight against the perpetrator, only in this way can they safeguard their legitimate rights and interests. Secondly, the victims should actively collect evidence to prove sexual harassment occurred. Most cases of sexual harassment occurred in the much hidden places, usually only the perpetrator and the victims are on the spot, and thus lack of direct witnesses, which make it essential that the victim must take the initiative to collect and extract relevant evidence in order to safeguard their legitimate rights and interests. The victims should use appropriate methods to obtain evidence, the documentary evidence and physical evidence should be preserved as original as possible, the cell phone information and e-mail can also be retained by technical means. For speech or action to sexual harassment, in addition to resist openly and timely to access to the necessary outside witnesses, the victims can also record the harasser's behavior by a variety of secret fidelity audio and video equipment. According to judicial interpretation issued by the Supreme Court, audio-visual information through photographing and videotaping stealthily, only do not infringe the legal rights of others or violate the law prohibitions, can be used as evidence, which provide an important legal protection for the victims' secret evidence. Thirdly, by a variety of ways to protect their legitimate interests make the perpetrator of sexual harassment deserve sanctions. The victims can report sexual harassment to internal disciplinary departments, ask the appropriate agencies of sexual harassment criticize and educate the perpetrator, to avoid the expansion of disputes, and strive to solve the problem within the enterprise. Victims can Complain to the labor administrative department, ask the labor administrative department investigate the sexual harassment occurred within the unit, not only make the perpetrator punished, but also make employers bear the responsibility since the enterprise is inade- quate to protect workers. This can reduce sexual harassment in the workplace radically and improve working conditions, solve the problem properly. For the more serious sexual harassment, the victims can go directly to the people's court to require the perpetrator to bear the corresponding civil liability, the infringer punished by law. In the lawsuit process, trade union organization should support actions to help collect evidence, to effectively protect the legitimate interests of employees.

\section{Countermeasures and Management Suggestions on Employees' Families Preventing and Solving Sexual Harassment in the Workplace}

Help from family members plays an important role in the prevention and resolution of sexual harassment in the workplace. Family members should pay attention to employees' dress in the usual, remind her dress decent in the workplace at the appropriate time, not too exposed, or does not match with the atmosphere of the workplace.

\section{Conclusion}

Through survey, the following conclusion is drawn. Sexual harassment in corporate workplace has become increasingly prominent. Verbal sexual harassment is becoming a common way of harassment in the workplace; most women experiencing sexual harassment in the workplace chose to require the company competent department or the police to solve.

Future research can expand the scope of sample selection more widely, so that research findings are more comparable and workable.

\section{Acknowledgements}

This paper is financially supported by The "QingLan Project” of Jiangsu Department of Education of P. R. China.

\section{REFERENCES}

Croney, S. T., \& Kleiner, B. H. (1995). Understanding and effectively managing sexual harassment. Equal Opportunities International, 21, 46-53. doi:10.1108/eb010649

Gary, L. W., \& Shirley, H. T. (1998). A theoretical integration of sexual harassment models. Equal Opportunities International, 24, 2129.

Maggie, T., \& Kleiner, B. H. (1999) How to investigate sexual harassment in the workplace. Equal Opportunities International, 25, 1-7.

Shen, Y. F. (2004). Generalization of the concept of sexual harassment, narrowing and response measures. Collection of Women's Studies, 34, $11-27$.

Wang, X. J. (1998). The status quo and research of sexual harassment. Collection of Women's Studies, 44, 39-44. 